\title{
Duration of S1, the most recent sapropel in the eastern Mediterranean Sea, as indicated by accelerator mass spectrometry radiocarbon and geochemical evidence
}

\author{
D. Mercone, J. Thomson, and I.W. Croudace \\ Southampton Oceanography Center, Empress Dock, Southampton, England \\ G. Siani, M. Paterne \\ Laboratoire des Sciences du Climat et de L'Environnement, Laboratoire Mixte CNRS-CEA, \\ Domaine du CNRS,Gif-sur-Yvette, France \\ S. Troelstra \\ Institute of Earth Sciences, Free University, Amsterdam
}

\begin{abstract}
Slowly accumulated ( $\left.<5 \mathrm{~cm} \mathrm{kyr}^{-1}\right)$ and rapidly accumulated $\left(5-20 \mathrm{~cm} \mathrm{kyr}^{-1}\right)$ sediments have been compared to define the initiation and termination times of the most recent sapropel (S1) in the eastern Mediterranean Sea. The $\mathrm{Ba} / \mathrm{Al}$ ratio has been employed as a more persistent index of productivity than $\mathrm{C}_{\text {org }}$. Accelerator mass spectrometry radiocarbon dating of pelagic foraminifera indicates a maximum duration for increased $\mathrm{Ba} / \mathrm{Al}$ levels in $\mathrm{S} 1$ from $~ 9500$ 6000 (uncorrected radiocarbon convention years B.P.) in the rapidly accumulated sediments and $\sim 9500-5300$ years B.P. in the slowly accumulated sediments. This difference is ascribed to bioturbation affecting the slower accumulated S1 sediments. In the two most rapidly accumulated S1 units, from the Adriatic and Aegean Seas, there is a "saddle" of lower values centered on 7500 years B.P. in the $\mathrm{C}_{\text {org }}$ and $\mathrm{Ba} / \mathrm{Al}$ profiles, so that the visual $\mathrm{S} 1$ unit appears as a doublet. Geochemical evidence indicates that this intervening period is best interpreted as an episode of increased ventilation and bottom water oxygenation during the period of sapropel accumulation.
\end{abstract}

\section{Introduction}

Dark-colored units, with sharply defined contacts, high organic carbon $\left(\mathrm{C}_{\text {org }}\right.$ ) contents and high $\mathrm{S}$ contents in the form of pyrite [Calvert, 1983; Passier et al., 1996] occur episodically in the otherwise $\mathrm{C}_{\text {org }}$-poor sedimentary record of the eastern Mediterranean Sea. Such units are termed sapropels [Kidd et al., 1978], and their repeated occurrence demonstrates the sensitivity of sedimentation in this topographically isolated basin to climatic changes [e.g., Emeis et al, 1996]. There is no agreement on the precise mechanisms or sequence of events that lead to sapropel formation because of the uncertainty on the relative roles of productivity and preservation in the development of high sediment $\mathbf{C}_{\text {org }}$ contents [Thunell and Williams, 1989; Calvert, 1983; Calvert and Pedersen, 1992; Bethoux, 1993; Rohling, 1994]. Sapropel formation does appear to be closely related to times of planetary Northern Hemisphere summer insolation maxima and resultant monsoon intensification [Rossignol-Strick et al., 1982; Lourens et al., 1996]. These wet periods are believed to induce enhanced water column stability and perhaps increased surface ocean productivity. The resultant decreased ventilation of the deep water column may then allow development of anoxia [or at least low oxygen levels] which may in turn lead to improved preservation of $\mathrm{C}_{\text {org }}$. Improved timing records of sapropel

\section{Copyright 2000 by the American Geophysical Union.}

Paper number 1999PA000397.

0883-8305/00/1999PA000397\$12.00 deposition may constrain cause and effect interpretations, and such records are most accessible for the most recent sapropel (S1 Hieke, [1976]) because it is within the radiocarbon dating range.

Geochemical studies of $S 1$ have revealed that although this sapropel is < $10 \mathrm{kyr}$ old, it has already suffered extensive postdepositional alteration which has oxidized $\mathbf{C}_{\text {org }}$ from the upper reaches of the original S1 unit [De Lange et al., 1989; Higgs et ah, 1994; Thomson et al., 1995, 1999; van Santwoort et al., 1996]. This carries implications for geochemical, micropaleontological, paleoenvironmental, and sedimentological studies because it means that the true duration of sapropel formation is not coincident with the visual evidence in the sediments but rather occurs over a longer sediment interval. Thomson et al., [1999] proposed that the $\mathrm{Ba} / \mathrm{Al}$ ratio was a more persistent criterion than color or $\mathrm{C}_{\text {org }}$ content for the study of sapropel productivity pulses, and this contention has been bome out in older sapropels [van Santvoort et al., 1997]. This paper uses a combination of the $\mathrm{Ba} / \mathrm{Al}$ ratio and accelerator mass spectrometry (AMS) radiocarbon data to study the development of $S 1$ in cores with different sediment accumulation rates and from different water depths, from widely separated eastern Mediterranean basin locations.

\section{Material and Methods}

Samples from box and piston cores from various eastern Mediterranean localities were obtained from the core archives at Free University, Amsterdam, Laboratoire des Sciences du 
Climat et de L'Environnement (LSCE), Gif-sur-Yvette, and British Ocean Sediment Core Repository (BOSCOR), Southampton (Table 1; and Figure 1). Cores were sub sampled at $1 \mathrm{~cm}$ intervals with sufficient sediment taken to give a dry weight of $>3 \mathrm{~g}$. Samples were freeze-dried or oven-dried at $105^{\circ} \mathrm{C}$ then ground and homogenized using a tungsten carbide swing mill. A Philips PW1400 automatic sequential wavelength dispersive $\mathrm{X}$-ray spectrometer was used to determine $\mathrm{Ba}$ and $\mathrm{S}$ on pressed powder pellets and $\mathrm{Al}$ and $\mathrm{Mn}$ on lithium meta-tetraborate fusion discs. Accuracy and precision were ascertained by running the international standard reference material MAG-1 (marine mud); the precision for trace element determination was $5 \%$ relative standard deviation (RSD), while for major element analyses it was typically $<1 \%$ RSD. Organic carbon and $\mathrm{CaCO}_{3}$ were determined coulometrically from released $\mathrm{CO}_{2}$. Inorganic $\mathrm{C}$ (biogenic calcium carbonate) was measured as the $\mathrm{CO}_{2}$ evolved by the addition of $10 \%(\mathrm{vol} / \mathrm{vol}) \mathrm{H}_{3} \mathrm{PO}_{4}$, and total $\mathrm{C}$ was measured as the $\mathrm{CO}_{2}$ generated by total sample combustion at $900^{\circ} \mathrm{C}$. Organic carbon $\left(\mathrm{C}_{\text {org }}\right)$ was then calculated as total $\mathrm{C}$ minus inorganic $\mathrm{C}$, and $\mathrm{CaCO}_{3}$ was calculated as 100 (inorganic $\mathrm{C}$ )/12. Precision for both $\mathrm{CaCO}_{3}$ and $\mathrm{C}_{\text {org }}$ analyses was determined by replicate analysis of an in-house standard (a deep-sea carbonate sediment) at $<1 \%$ RSD for $\mathrm{CaCO}_{3}$ and $<3 \%$ RSD for $\mathrm{C}_{\text {org }}$ measurements, respectively.

Planktonic foraminifera $>150 \mu \mathrm{m}$ in size were handpicked for AMS radiocarbon analysis because they have an unequivocal surface ocean source and are the sediment size fraction least liable to post-depositional transport (Troelstra et al., 1991). Species differentiation was not attempted because the total sediment sample available $(-5 \mathrm{~g}$ wet) was often sufficient only to provide the $10-12 \mathrm{mg}$ of biogenic $\mathrm{CaCO}_{3}$ in the $>150 \mu \mathrm{m}$ size range necessary for a single AMS analysis. Samples were prepared as graphite targets at the NERC Radiocarbon Laboratory and analyzed at the Lawrence Livermore National Laboratory AMS Facility (CAMS analyses) or at the Scottish Universities Research and Reactor Center and analyzed at the Arizona Radiocarbon Facility (AA analyses). Further species specific (Globigerinoides bulloides or $G$. ruber) AMS radiocarbon analyses from LSCE were available for one core (Siani, 1999, GifA analyses, Table 2).

\section{Results and Discussion}

Primary production of $\mathrm{C}_{\text {org }}$ and its preservation in the sediments are separated by remineralization by oxic or anoxic mechanisms during sinking through the water column and after deposition at the seafloor. Although sapropel S1 is the sediment record of a sustained phase of either or both increased surface ocean productivity and improved $\mathrm{C}_{\text {org }}$ preservation, it is not yet clear whether either the start or finish of $\mathrm{S} 1$ can be regarded as exactly synchronous across the entire eastern Mediterranean basin (Troelstra et al., 1991; Fontugne et al., 1994; Strohle and Krom, 1997). Vergnaud-Grazzini et al. (1986) estimated the duration of S1 to be 9000-7000 years from a review of early radiocarbon analyses. The compilation by Fontugne et al. (1994), which included newer AMS radiocarbon data, also returned a modal value of 9000-7000 years, although outlier values in the range $15000-4000$ years were encountered.

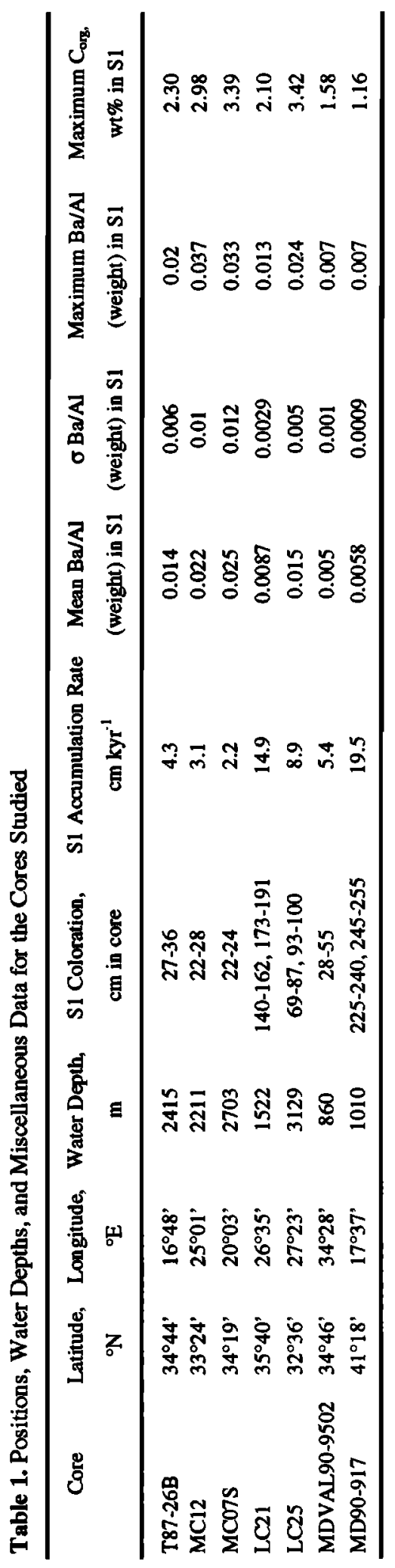




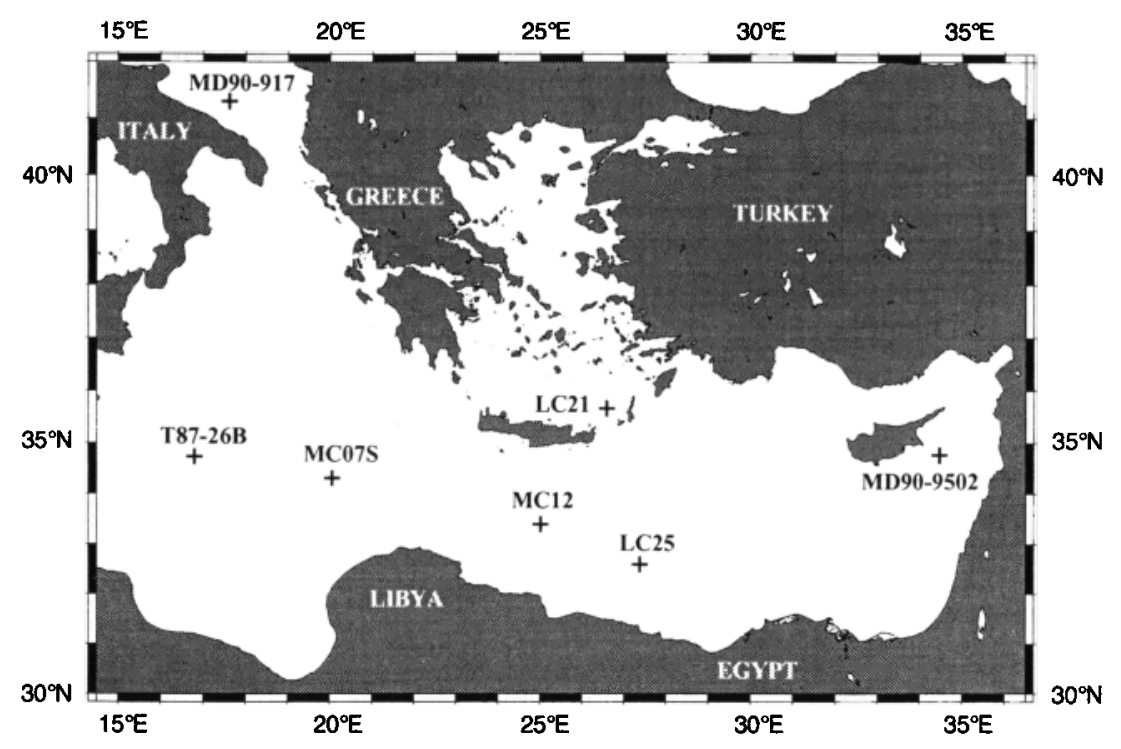

Figure 1. Map of core positions in the eastern Mediterranean Sea.

Sapropel S1 is evident in most cores as a single, dark, $\mathrm{C}_{\text {org }}$ rich horizon up to $-10 \mathrm{~cm}$ thick. The visual $S 1$ units in certain cores studied here are unusually thick at up to $50 \mathrm{~cm}$, and in some the dark coloration is in two parts (Table 1). "Double" S1 units have been reported before from various eastern Mediterranean localities (see listing by Rohling et al. [1997]), although these have often been ascribed implicitly or explicitly to sedimentological disturbances. High mean accumulation rates can be the result of high surface-ocean productivity or land-derived detrital fluxes, but they can also result from down-slope redeposition of sediment or from a current-driven augmentation of accumulation in the form of drift deposits or contourites. Redeposition from turbidites will produce a discontinuous sediment record, while contourite formation may produce continuous but irregular records reflecting the waxing and waning of current strength through time. Sediment redeposition is certainly a common process in the Mediterranean basin, and Stanley [1985] estimates that two thirds of the volume of recent basin sediments are affected by downslope mass flow. It is therefore necessary to establish whether or not redeposition has affected the studied cores and, in particular, to validate the accumulation records containing double sapropels. This involves assessment of whether either or both sections are of S1 age, whether both dark sections represent continuous accumulation, and the nature of the central lighter zone. This is achieved by defining $S 1$ in terms of the $\mathrm{Ba} / \mathrm{Al}$ productivity index rather than $\mathrm{C}_{\text {org }}$ content or color and by using multiple AMS radiocarbon ages to confirm that the units are consistently of $\$ 1$ age.

\subsection{Productivity Records From Ba/Al and $\mathrm{C}_{\text {org }}$}

The element $\mathrm{Ba}$ is central to the geochemical interpretation of the productivity fluctuations recorded by S1. From the work of J.Dymond and coworkers [Dymond et al., 1992, Dymond and Collier, 1996] it is established that settling material from surface ocean organic productivity develops a Ba enrichment during its descent through the water column before deposition.
At times of high productivity this flux of biogenic $\mathrm{Ba}\left(\mathrm{Ba}_{\mathrm{bio}}=\right.$ measured $\mathrm{Ba}$ - measured $\left.\mathrm{Al} \times[\mathrm{Ba} / \mathrm{Al}]_{\text {decrial }}\right)$ becon'es sufficiently large that it may be readily identified against detrital $\mathrm{Ba}$ in the sediments through increases in the sediment $\mathrm{Ba} / \mathrm{Al}$ ratio. Normalization to $\mathrm{Al}$ is necessary because of the dilution effects of $\mathrm{CaCO}_{3}$ content on the assumption that detrital phases have fairly constant $\mathrm{Al}$ and $\mathrm{Ba}$ contents which dominate the trace $\mathrm{Ba}$ content of $\mathrm{CaCO}_{3}$. Barium has been used in this manner as a palaeoproductivity indicator for many years, but the mechanism and rate of progressive $B a_{b 10}$ enrichment in settling $\mathbf{C}_{\mathrm{org}}$, and therefore its quantification, remain elusive [Dymond and Collier, 1996]. In the case of eastern Mediterranean sapropels, there is the added uncertainty of the behavior of $\mathrm{Ba}$ in anoxic or poorly oxygenated as opposed to oxic water columns.

In S1 examples previously investigated [Thomson et al., 1995; van Santvoort et al., 1996, 1997], the presence of high$\mathrm{Ba}$ but low- $\mathrm{C}_{\mathrm{org}}$ levels immediately above visual $\mathrm{S} 1$ units has been taken as evidence that postdepositional oxidation of $\mathrm{S} 1$ has remineralized $\mathrm{C}_{\text {org }}$ but has not affected $\mathrm{Ba}_{\text {bio. }}$. This pattern is again observed in core $\mathrm{T} 87-26 \mathrm{~B}$, where the $\mathrm{Ba} / \mathrm{Al}$ ratio profile relative to the $C_{\text {org }}$ and $S$ profiles (both of which suffer oxidation loss) indicates that $-9 \mathrm{~cm}$ of oxidation has occurred (lighter shaded area of Figure 2). A corollary of this interpretation from slowly accumulated $\mathrm{S} 1 \mathrm{Ba} / \mathrm{Al}$ and $\mathrm{C}_{\text {org }}$ profiles is that less oxidized and, consequently, less altered examples ought to exist in areas of rapid accumulation, but this has not been demonstrated until now. The sediments of cores MD81-LC21 and MD90-917 are the most rapidly accumulated among those studied (15 and $20 \mathrm{~cm} \mathrm{kyr}^{-1}$, respectively, see below), and these two cores are used to test the prediction of an initial correspondence between the $\mathrm{Ba} / \mathrm{Al}$ ratio and $\mathrm{C}_{\text {org }}$ contents in the absence of post depositional oxidation.

The $\mathrm{Ba} / \mathrm{Al}$ ratio and $\mathrm{C}_{\text {org }}$ contents of the dark intervals in MD81-LC21 and MD90-917 are consistently higher than in the enclosing sediments, both profiles have a similar doublepeak shape (Figure 3), and there is a good correlation between 
Table 2. Radiocarbon Convention Ages Obtained by the Accelerator Mass Spectrometric Technique

\begin{tabular}{|c|c|c|c|c|c|}
\hline Core & $\begin{array}{c}\text { Depth in Core, } \\
\text { cm }\end{array}$ & $\begin{array}{l}\text { Analysis } \\
\text { Code }\end{array}$ & $\begin{array}{c}{ }^{14} \mathrm{C} \text { age, } \\
\text { convention years }\end{array}$ & $\begin{array}{l} \pm 1 \sigma \\
\text { years }\end{array}$ & $\begin{array}{c}\delta^{13} \mathrm{C} \\
\text { (per mille) }\end{array}$ \\
\hline MDVAL90-9502 & $25-26^{*}$ & AA-28393 & 5,830 & 55 & n.d \\
\hline MDVAL90-9502 & $30-31^{*}$ & AA-28394 & 6,980 & 60 & n.d \\
\hline MDVAL90-9502 & $41-42$ & AA-28395 & 7,940 & 60 & n.d. \\
\hline MDVAL90-9502 & $53-54^{*}$ & AA-28396 & 7,530 & 60 & n.d. \\
\hline MDVAL90-9502 & $57-58 *$ & AA-28397 & 8,150 & 65 & n.d. \\
\hline LC21 & $49.5-50.5$ & CAMS-41314 & 3,370 & 60 & -1.0 \\
\hline LC21 & $95-96$ & CAMS -41313 & 4,290 & 60 & 1.2 \\
\hline LC21 & $137-138^{*}$ & CAMS-41311 & 5,590 & 60 & 0.4 \\
\hline LC21 & $161-162 *$ & CAMS-41315 & 7,480 & 60 & 0.9 \\
\hline $\mathrm{LC} 21$ & $174-174.5^{*}$ & CAMS-41312 & 8,120 & 60 & -0.1 \\
\hline LC21 & $188-191^{*}$ & AA-30364 & 9,085 & 65 & n.d. \\
\hline LC21 & $218.5-219.5$ & AA-30365 & 11,765 & 80 & n.d. \\
\hline LC21 & $252-253$ & CAMS-41316 & 14,450 & 60 & 0.3 \\
\hline $\mathrm{LC} 25$ & $50-51 *$ & AA-30366 & 4,805 & 50 & n.d. \\
\hline LC25 & $60-61 *$ & CAMS-43635 & 6,320 & 60 & 1.0 \\
\hline LC25 & $70.5-71.5 *$ & CAMS-43636 & 7,270 & 50 & -0.2 \\
\hline LC25 & $84.5-85.5^{*}$ & CAMS-43637 & 8,770 & 50 & -1.0 \\
\hline LC25 & $92-93$ & CAMS-43638 & 8,980 & 60 & 0.5 \\
\hline LC25 & $225-226$ & CAMS-43639 & 11,110 & 50 & 1.0 \\
\hline MD90-917 & $164-167^{=}$ & GifA-96201 & 4,750 & 70 & \\
\hline MD90-917 & $175-178^{=}$ & GifA-96202 & 5,000 & 70 & \\
\hline MD90-917 & $190-192^{=}$ & GifA-96729 & 5,680 & 70 & \\
\hline MD90-917 & $221-222 *$ & CAMS-45865 & 6,500 & 60 & n.d. \\
\hline MD90-917 & $229-230^{*}$ & CAMS-45866 & 6,990 & 40 & n.d. \\
\hline MD90-917 & $230-232 *=$ & GifA-96730 & 6,920 & 90 & - \\
\hline MD90-917 & $239-242^{*}=$ & GifA-96203 & 7,930 & 80 & - \\
\hline MD90-917 & $242-243^{*}$ & CAMS-45867 & 7,750 & 210 & n.d. \\
\hline MD90-917 & $250-253.5^{*}=$ & GifA-96204 & 8,020 & 70 & \\
\hline MD90-917 & $250-253.5^{*}=$ & GifA-96205 & 8,170 & 70 & \\
\hline MD90-917 & $251-252^{*}$ & CAMS-45868 & 7,910 & 140 & n.d. \\
\hline MD90-917 & $252-253^{m}=$ & GifA-96731 & 8,040 & 90 & - \\
\hline MD90-917 & $258-259$ & CAMS-45869 & 9,750 & 80 & n.d. \\
\hline MD90-917 & 275-278 & GifA-96207 & 10,390 & 90 & \\
\hline MD90-917 & $295-297^{=}$ & GifA-96732 & 10,800 & 90 & \\
\hline
\end{tabular}

Here n.d. means not determined.

*Depths were used in calculation of regression lines in text.

$=$ These are monospecific samples (G. bulloides or G.ruber).

$\mathrm{Ba} / \mathrm{Al}$ and $\mathrm{C}_{\text {org }}$ (Figure 4). The maximum $\mathrm{C}_{\text {org }}$ and $\mathrm{Ba} / \mathrm{Al}$ levels in the core LC21 S1 both consistently exceed those of core 90 917 , although the slope of the $\mathrm{Ba} / \mathrm{Al}: \mathrm{C}_{\text {org }}$ relationship is similar in the two cores (Figure 4). Most of the $C_{\text {org }}$ values in both cores fail to achieve the $>2 \% \mathrm{C}_{\text {org }}$ criterion proposed by Kidd et al. [1978] to define a sapropel, but this criterion appears to be only an approximate guide to the $\mathbf{C}_{\text {org }}$ content necessary to develop the dark color of sapropels [Calvert, 1983]. In low accumulation rate S1 examples, Thomson et al. [1995] and van
Santvoort et al [1996] noted that the $\mathrm{S} 1 \mathrm{Ba} / \mathrm{Al}$ ratio depth profile is quasi-Gaussian in shape. The improved resolution provided by the rapid accumulation rates of MD81-LC21 and MD90-917 shows central "saddle" sections in the $\mathrm{Ba} / \mathrm{Al}$ and $\mathrm{C}_{\text {org }}$ profiles of both cores that are responsible for the double sapropel feature. Although values in these central sections are lower than those in the over-lying and underlying dark units, they are also markedly higher than the "background" levels which predate and postdate the S1 productivity pulse where 


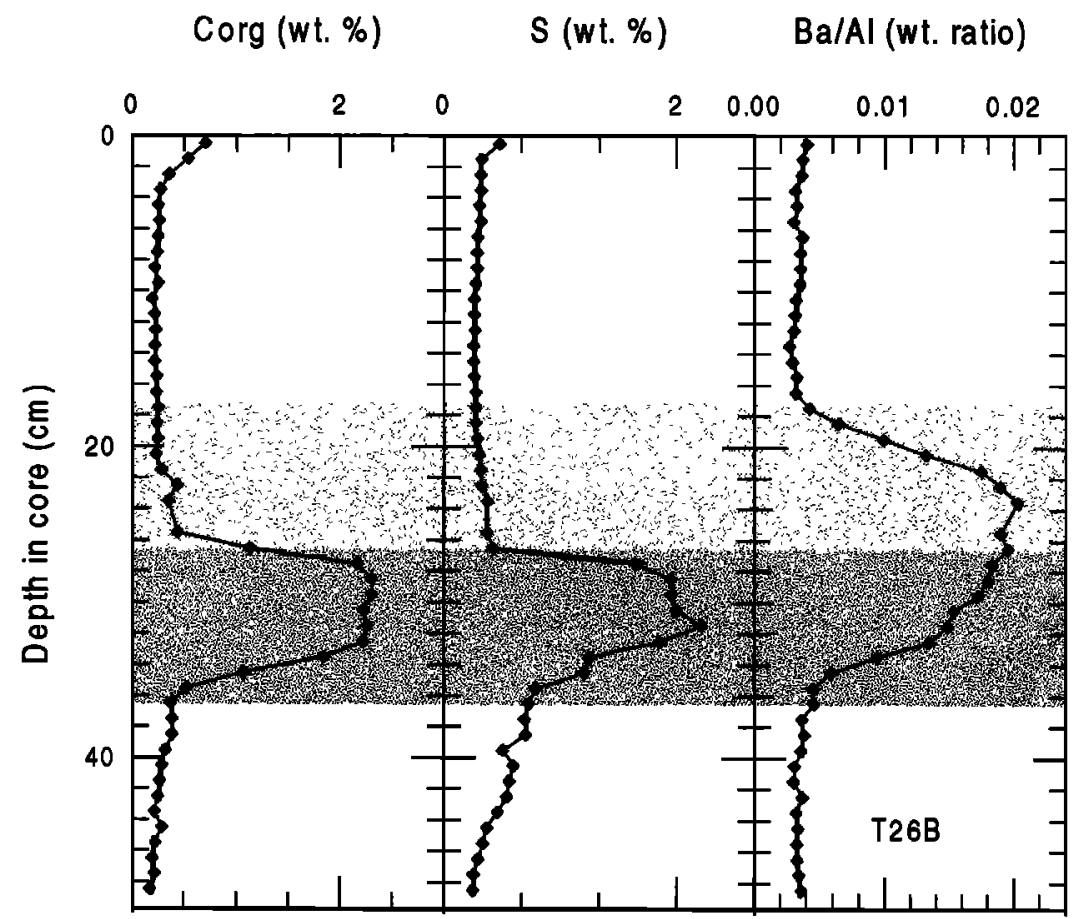

Figure 2. Profiles of $\mathrm{C}_{\text {agg }} \mathrm{S}$ (weight \%), and $\mathrm{Ba} / \mathrm{Al}$ (weight) ratio (right-hand scale) in the slowly accumulated sediments of core T87-26B [Troelstra et al., 1991]. The upper portion of the original S1 inferred to have been oxidized is shown in lighter shading, whereas the residual $\mathrm{C}_{\alpha \mathrm{ag}}$-rich unit is indicated by darker shading. Similar profiles have been described previously by Thamson et al. [1995] and van Santvoort et al. [1996].

$\mathrm{Ba} / \mathrm{Al}$ is $<0.004$ and $\mathrm{C}_{\text {org }}$ is $<0.5 \mathrm{wt} \%$. The significance of this central section in these two cores will be discussed further below.

\subsection{Rates of Accumulation From Radiocarbon Data}

As in most previous AMS radiocarbon dating of sapropel S1, radiocarbon data (Table 2) are quoted throughout this paper as unmodified radiocarbon convention ages in years before present (B.P., i.e., before 1950 A.D.). The quoted ages are neither corrected for the surface ocean reservoir effect

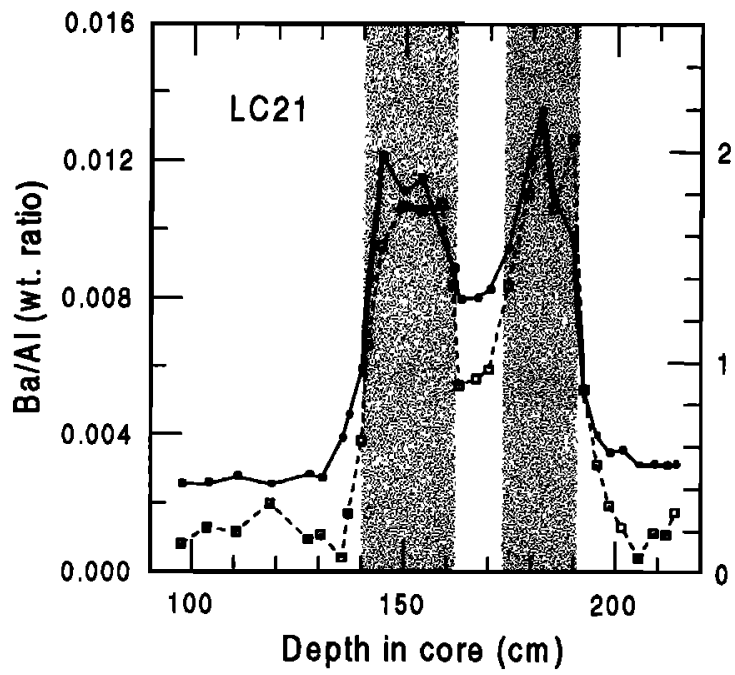

which is $~ 400$ years in the present-day ocean [Bard, 1988; Siani et al., 1999] nor corrected for the time-varying difference between calibrated (dendrochronological) time and radiocarbon convention time. This difference is +730 to +990 years in the radiocarbon convention time range 5000-9000 years B.P. [Stuiver and Becker, 1993; Kromer and Becker, 1993]. As a combined result of these two effects, the marine radiocarbon convention ages used here are expected to underestimate calibrated time by $300-600$ years in the marine radiocarbon time range $5000-9000$ years B.P. [Stuiver and Braziunas, 1993].

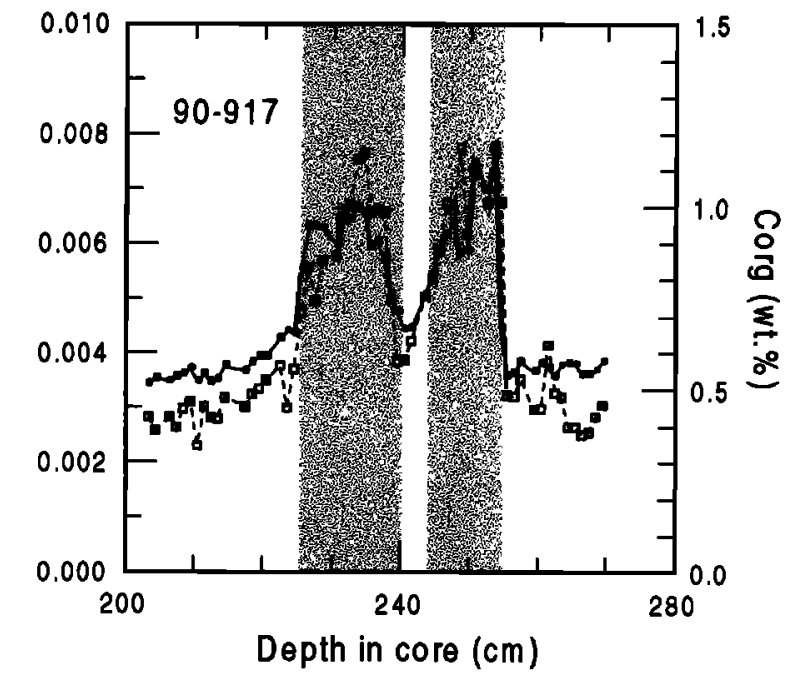

Figure 3. Profiles of $\mathrm{C}_{\text {org }}$ (weight \%) content (squares; right-hand scales) and Ba/Al (weight) ratio (circles; left-hand scales) as a function of depth in the rapidly accumulated sediments of cores (left) MD81-LC21 and (right) MD90-917. Note that there is a good coincidence between the $\mathrm{Ba} / \mathrm{Al}$ and $\mathrm{C}_{\text {org }}$ profiles shapes from these cores, unlike the core in Figure 2. The visual S1 units are shaded. 


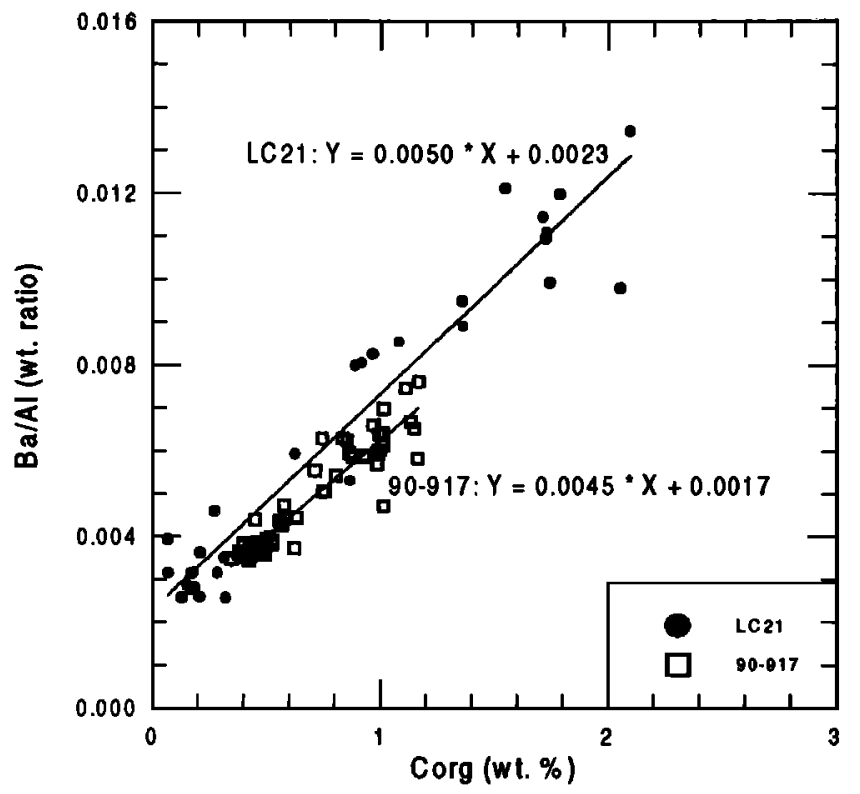

Figure 4. Correlations between the $\mathrm{Ba} / \mathrm{Al}$ and $\mathrm{Cog}_{\mathrm{g}}$ data for cores MD81LC21 (circles) and MD90-917 (squares) displayed in Figure 3. The lines shown are regressions of $\mathrm{Ba} / \mathrm{Al}$ on $\mathrm{C}_{\text {org }}$ for each core.

To achieve a common basis on which to compare the different $\mathrm{S} 1$ units, a chronology for the sapropel region in each core is derived by fitting a linear regression of marine radiocarbon convention age on depth. In some cores the radiocarbon data show that whole core rates of accumulation have been irregular through time, and in such cases, age values immediately above, within, and immediately below the S1 unit are preferred for construction of local floating regressions in the vicinity of the units. The explicit assumption in selective omission of data points is that any redeposition process must introduce sediment with a radiocarbon age older than newly deposited sediment, and such ages are therefore expected to exceed the regression lines through selected data.

3.2.1. Low ( $<5 \mathrm{~cm} \mathrm{kyr}^{-1}$ ) accumulation rate sediments: Cores T87-26B, MC7S, and MC12. AMS radiocarbon analyses have been reported for box core T87-26B [Troelstra et al., 1991] and multicores MC12 and MC07S [Thomson et al., 1995]. All the AMS radiocarbon data for T26B were regressed on depth to give a whole core accumulation rate (Figure 5a). The accumulation rates for these three cores (2.2$4.3 \mathrm{~cm} \mathrm{kyr}^{-1}$ ) are typical of those measured in the central Mediterranean basin but are slower than those for the cores discussed below.

3.2.2. Low ( $<5 \mathrm{~cm} \mathrm{kyr}^{-1}$ ) accumulation rate sediments: Core MDVAL $90-9502$. This core from the far east of the Mediterranean basin (Figure 5b) contains a dark visual unit from 28 to $65 \mathrm{~cm}$, and it was sampled with the expectation that it was a rapidly accumulated $S 1$ unit. Although the radiocarbon data confirm that the dark unit is entirely of S1 age, the progression of radiocarbon age on depth is irregular, and this core is now interpreted as a slowly accumulated unit with redeposition of sapropel material with higher $\mathrm{Ba} / \mathrm{Al}$ values in the center of the dark unit. Unlike the other cores where redeposition is inferred, compositional data do not indicate unequivocally the precise depths of the re-deposited section in this core because the redeposited material is also sapropelic. The depositional record is estimated from the extrapolations of the lines between the upper and lower data point pairs as shown (Figure 5b). The section from 32 to $52 \mathrm{~cm}$ is then inferred to be redeposited and disregarded in subsequent discussion. Note that the line between the upper two points intercepts the origin on extrapolation. This is the least secure interpretation of all the cores studied.

3.2.3. Intermediate $\left(5-10 \mathrm{~cm} \mathrm{kyr}^{-1}\right)$ accumulation rate sediments: Core MD81-LC25. On the basis of the $\mathrm{Ba} / \mathrm{Al}$ criterion, $\mathbf{S} 1$ is present in this Herodotus Abyssal Plain piston

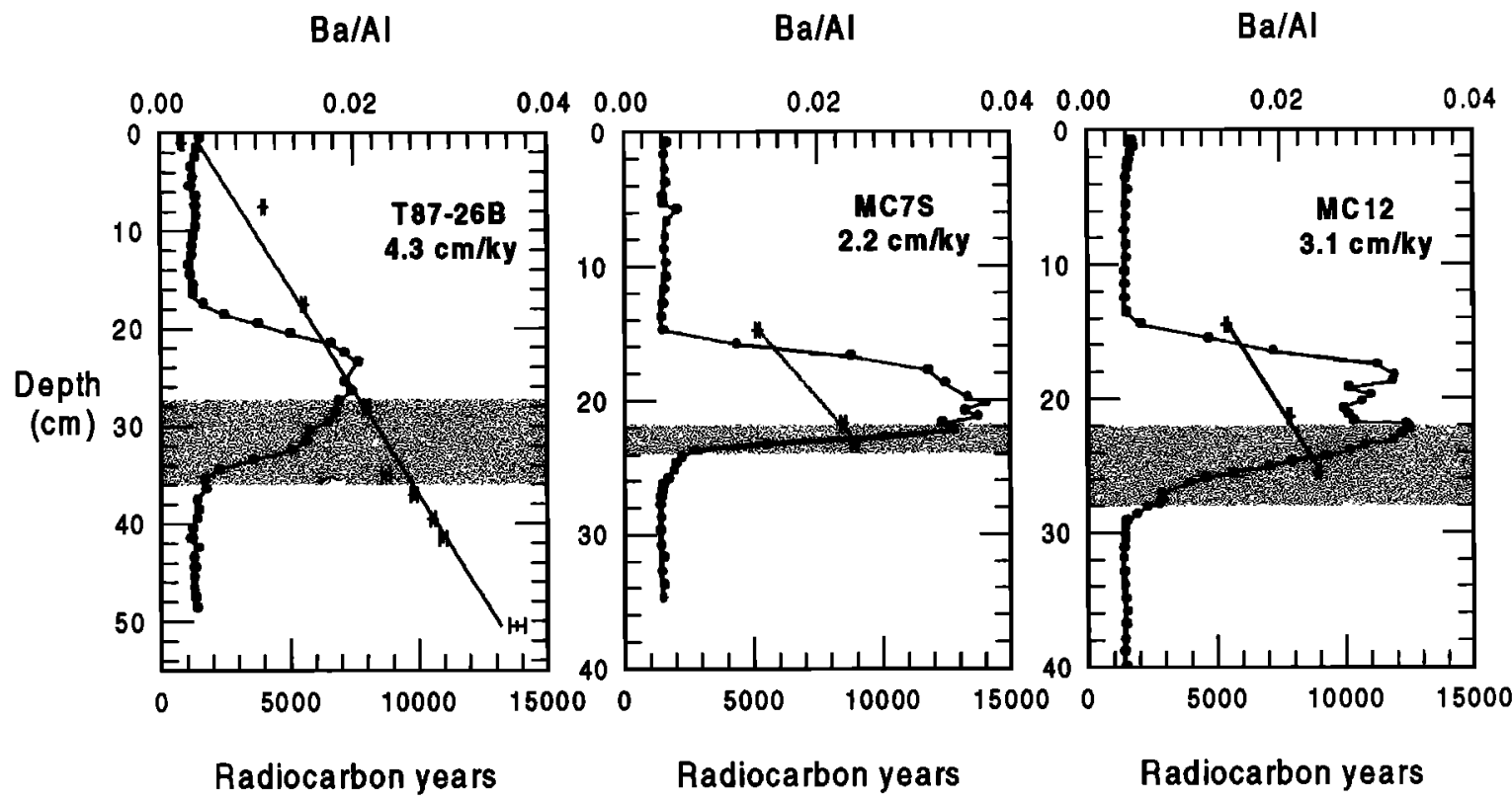

Figure 5a. Uncorrected radiocarbon convention ages for $>150 \mu \mathrm{m}$ planktonic foraminifera fractions and $\mathrm{Ba} / \mathrm{Al}$ ratio as a function of depth in cores T87-26B, MC7S, and MC12. The lines are regressions of radiocarbon age on depth which yield the accumulation rates shown. The visual $\$ 1$ units are shaded. 

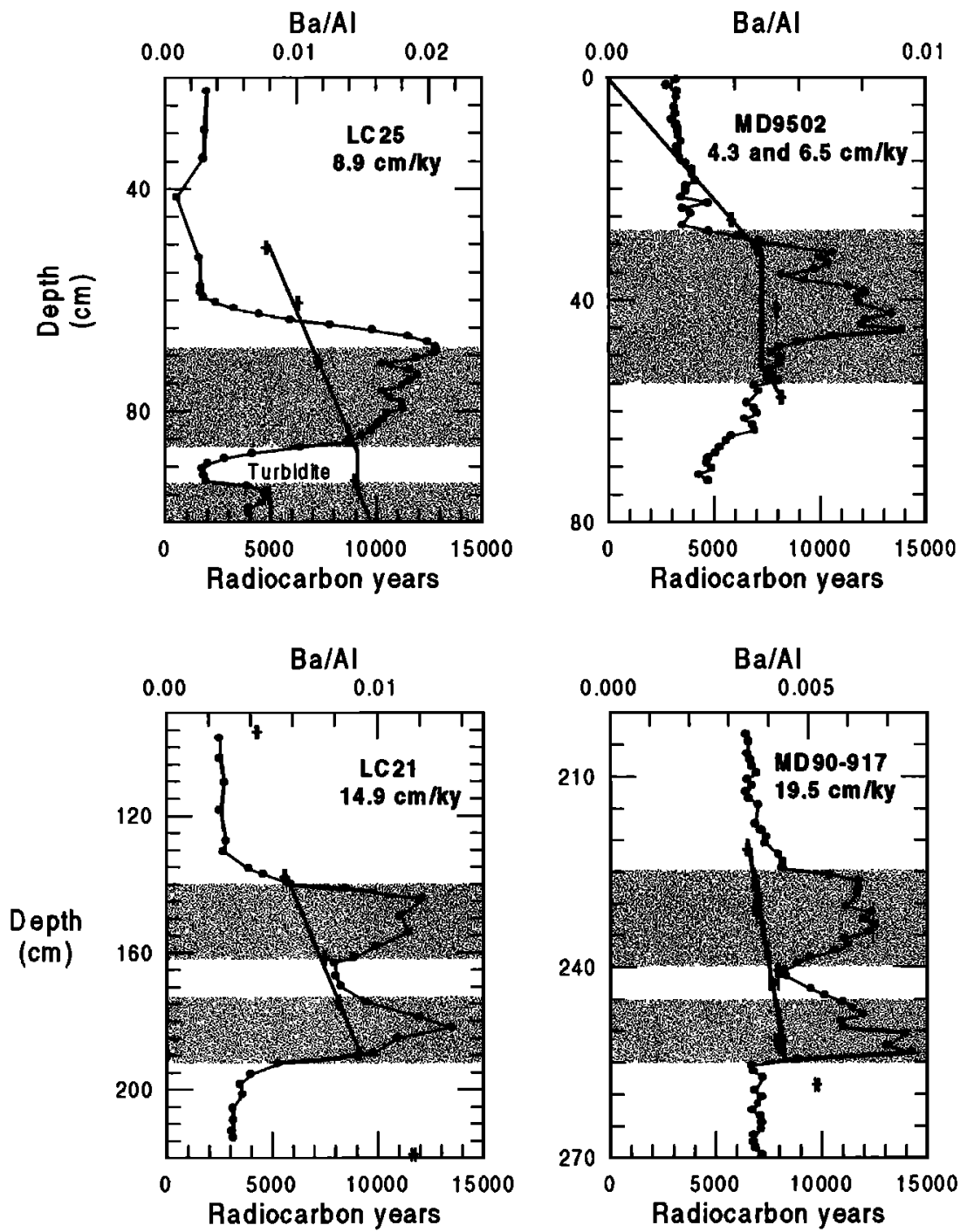

Figure $5 \mathrm{~b}$. Uncorrected radiocarbon convention ages for $>150 \mu \mathrm{m}$ planktonic foraminifera fractions and $\mathrm{Ba} / \mathrm{Al}$ ratio as a function of depth in cores LC25, MD9502, LC21, and MD90-917. The lines are regressions of radiocarbon age on depth which yield the accumulation rates shown in the vicinity of the S1 units. The visual S1 units are shaded. Note that core LC25 contains a turbidite at $87-93 \mathrm{~cm}$, and redeposition is inferred in core MD9502 from 32 to $52 \mathrm{~cm}$.

core from 61 to $87 \mathrm{~cm}$ and 94 to $100 \mathrm{~cm}$. The intervening section at $87-94 \mathrm{~cm}$ is clearly a turbidite on visual and compositional evidence (Figure 5b). Several other turbidites deposited before and after $\mathrm{S} 1$ are also present in this core, one of which is $1.2 \mathrm{~m}$ thick and has its top at $100 \mathrm{~cm}$ in core. From their dark color and mineralogy both turbidites emplaced during S1 time have been interpreted to originate from slope failures on the Nile fan [Cita et al., 1984; Reeder et al., 1998]. The regression line $\left(8.9 \mathrm{~cm} \mathrm{kyr}^{-1}\right)$ to establish accumulation rate was determined from the upper four radiocarbon analyses in the section with high $\mathrm{Ba} / \mathrm{Al}$ values and extrapolated into the section at depths 94 tol $00 \mathrm{~cm}$ by subtraction of $7 \mathrm{~cm}$ to account for the presence of the smaller turbidite at 87 to $94 \mathrm{~cm}$. It was not possible to locate the base of $\mathbf{S 1}$ in this core because the pelagic sample at $225 \mathrm{~cm}$ underlying the larger turbidite at 100 to $224 \mathrm{~cm}$ had background $\mathrm{Ba} / \mathrm{Al}$ levels, and its radiocarbon age clearly predated S1 (Table 2 ).

3.2.4. Rapid ( $>10 \mathrm{~cm} \mathrm{kyr}^{-1}$ ) accumulation rate sediments: Core MD81-LC21. The radiocarbon data from this piston core from the southeast Aegean Sea do not all conform to a straight line, indicating that its accumulation rate has been variable in time (Figure $5 b$ ). Besides containing a double $\mathbf{S 1}$ unit, this core contains a thick-gray ash layer from 82 to $92 \mathrm{~cm}$ that was suspected to have been deposited from the explosive eruption of the Santorini/Thera volcano [Guichard et al., 1993; Hardy and Renfrew, 1990]. Recent estimates place the Santorini event at 1627/1628 B.P., [Kuniholm et al., 1996] which corresponds to a radiocarbon convention age of $\sim 3300-$ 3400 years [Stuiver and Becker, 1993; Bruins and van der Plicht, 1996], so that the best estimate for the corresponding marine radiocarbon convention age is $\sim 3700-3800$ yr. The actual radiocarbon determinations $32 \mathrm{~cm}$ above and $3 \mathrm{~cm}$ below the ash layer in MD81-LC21 are 3370 and 4290 radiocarbon years, respectively, which by interpolation, indicates an age of $\mathbf{4 2 1 0}$ years for the ash level. This straddling of the probable Santorini age estimate by the data is taken as confirmation that the ash layer in core MD81-LC21 is, in fact, from Santorini, even though the interpolated layer age is -450 
years older than expected. The effects of bioturbation in the surface sediment mixed layer are expected to have increased the radiocarbon age of surficial sediment blanketed by the ash fall [Trauth et al., 1997].

From the eight AMS radiocarbon analyses available for this core the four analyses spanning the depth range $137-191 \mathrm{~cm}$ were selected to estimate a mean accumulation rate of $14.9 \mathrm{~cm}$ $\mathbf{k y r}^{-1}$ by linear regression (Figure $5 \mathrm{~b}$ ). The duration of the light-colored central section $(162-173 \mathrm{~cm})$ is estimated by this regression at $7320-8060$ years.

3.2.5. Rapid (>10 $\mathrm{cm} \mathrm{kyr}^{-1}$ ) accumulation rate sediments: Core MD90-917. Additional monospecific foraminiferal AMS ages for core MD90-917 from the southern Adriatic Sea [Siani, 1999] reveal that the sapropelic sediments accumulated more rapidly than the sediments which preceded and postdated them. (Only values immediately above, in, and below the S1 unit of the available GifA ages are included in Table 2 and Figure $5 \mathrm{~b}$.) The regression of the nine AMS radiocarbon analyses in the depth range $221-253.5 \mathrm{~cm}$ yields a sediment accumulation rate of $19.5 \mathrm{~cm} \mathrm{kyr}^{-1}$. The duration of the lightcolored central section at $240-245 \mathrm{~cm}$ is estimated at 7520 7780 years by this regression.

\subsection{S1 Development in Slowly Accumulated Sediments}

The fits to the radiocarbon data derived above allow the $\mathrm{Ba} / \mathrm{Al}$ records of all cores to be compared directly as a function of time by conversion of sample depth to radiocarbon convention years with the individual regression equations. When the $\mathrm{Ba} / \mathrm{Al}$ profiles of cores $\mathrm{T87}-26 \mathrm{~B}, \mathrm{MC07S}$, and $\mathrm{MC1} 2$ (Figure 5a) are compared as a function of radiocarbon time over 4000-10,000 years, a striking agreement is found between the three slowly accumulated core records (Figure 6a). In all cases the increase in productivity indicated by the increase in the $\mathrm{Ba} / \mathrm{Al}$ ratio begins after 10,000 years and ends at $\sim 5300$ years, a considerably longer span of time than the $9000-7000$ years interval usually quoted for the duration of S1 [Vergnaud-Grazzini et al., 1986; Fontugne et al., 1994].

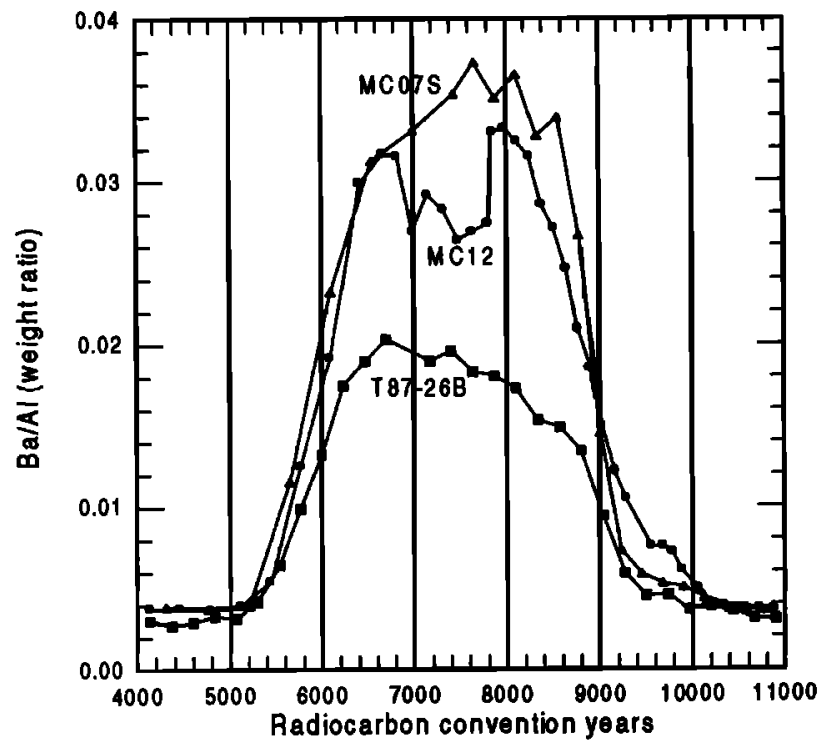

Figure 6a $\mathrm{Ba} / \mathrm{Al}$ ratio as a function of radiocarbon time (uncorrected convention years) in cores MC12, MC07S and T87-26B with slowly accumulated sediments.

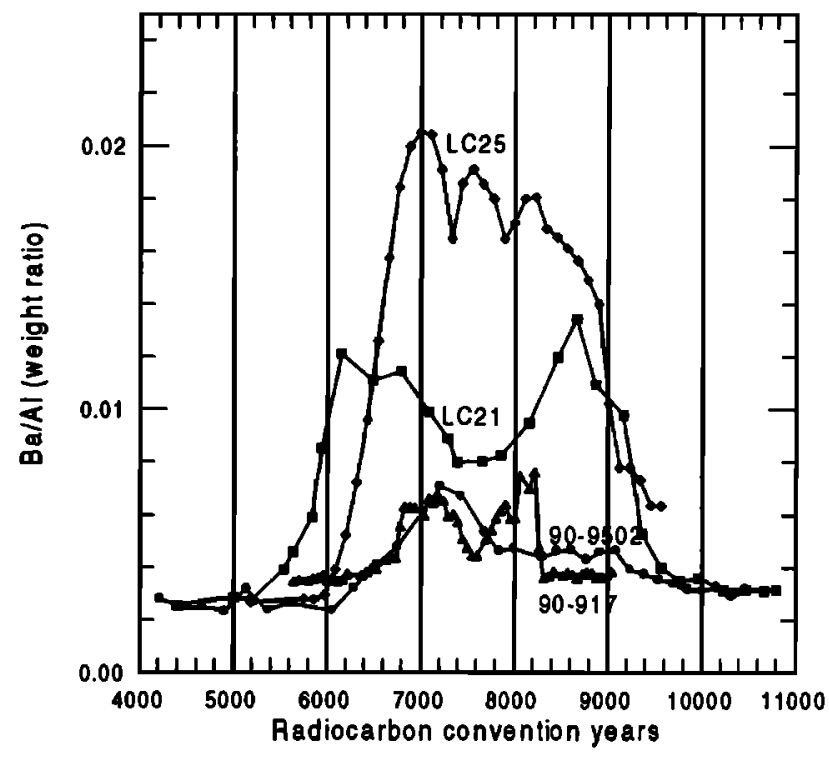

Figure 6b. Ba/Al ratio as a function of radiocarbon time (uncorrected convention years) in core MDVAL 90-9502 with slowly accumulated sediments and cores LC21, LC25, and 90-917 with rapidly accumulated sediments.

\subsection{S1 Development in Rapidly Accumulated Sediments}

When the $\mathrm{Ba} / \mathrm{Al}$ indexes of the sediments that accumulated at 10-20 $\mathrm{cm} \mathrm{kyr}^{-1}$ and the MDVAL 90-9502 data are plotted as a function of radiocarbon time, a less coherent picture of the S1 $\mathrm{Ba} / \mathrm{Al}$ episode emerges than was seen for the slowly accumulated sediments (Figure 6b). The initiation of high $\mathrm{Ba} / \mathrm{Al}$ ratio values and hence $S 1$ formation is clearly underway in all cores by 9000 years except for Adriatic core 90-917. High $\mathrm{Ba} / \mathrm{Al}$ values in this latter core start later and end earlier (8200-6300 years) so that they are present over a much more restricted time interval than in any other core.

The high $\mathrm{Ba} / \mathrm{Al}$ values of the $\mathrm{S} 1$ pulse end by 6000 years in all of the rapidly accumulated sediments except those in core LC21, several hundred years earlier than the end of high $\mathrm{Ba} / \mathrm{Al}$ indicated in the slowly accumulated sediments. Few radiocarbon ages $<6000$ years have been reported for $\mathrm{C}_{\text {org }}$-rich S1 material [Perissoratis and Piper, 1992], but the value of $5590 \pm 60$ years in the $137-138 \mathrm{~cm}$ interval in core MD81-LC21 is immediately above the upper face of the S1 unit and is in trend with the remainder of data in this core (Figure 5b).

At face value, the differences in time between the slowly and rapidly accumulated sediments might represent a slightly earlier start and later end to sapropel formation in the slowly accumulated sediments. As these three box cores are generally from greater water depths than the rapidly accumulated sediments (Table 1), it is conceivable that water column anoxia might have developed earlier and been maintained longer in the deeper parts of the basin. This is contrary to the arguments of Strohle and Krom [1997] who envisaged that S1 formation occurred first in a midwater oxygen minimum zone that subsequently expanded downward. The Herodotus Abyssal Plain core MD81-LC25 is critical to the water depth argument because it is from the deepest water depth of the available cores. High productivity in that core begins before 9000 years B.P. and is completed by 6100 years B.P. (Figure 6b), so that it does not appear as if the offsets in $\mathrm{S} 1$ time can be related simply to water depth. 
A different possibility is that the difference between the slowly and rapidly accumulated cores is a function of bioturbative mixing affecting both the AMS radiocarbon ages and the $\mathrm{Ba} / \mathrm{Al}$ ratio values before and after sapropel formation in the slowly accumulated cores. Thomson et al. [1995] have demonstrated by means of ${ }^{210} \mathrm{~Pb}_{\text {exess }}$ distributions that the present-day sediment surface mixed layer (SML) in deep basin cores is $<3 \mathrm{~cm}$ deep on the 100 year timescale, which corresponds to a mixing of up to 1000 years of deposition in these slowly accumulated sediments. Most open ocean deepsea cores have SMLs $9.8 \pm 4.5 \mathrm{~cm}$ thick [Boudreau, 1994], and thin SMLs are most likely a consequence of a low flux of $\mathrm{C}_{\text {org }}$ reaching the present-day sea floor in the eastern Mediterranean, as observed in oligotrophic regions elsewhere [Legeleux et al., 1994]. Bioturbation may have been more intense immediately before and after S1 formation when bottom water oxygen content was still finite but the surficial sediments had high $\mathrm{C}_{\text {org }}$ contents. In this view the chronologies from the rapidly accumulated $S 1$ units must be preferred over those from the slowly accumulated units because the former are less sensitive to bioturbation artifacts. Our best estimate for the duration of $\mathrm{S} 1$ based on the $\mathrm{Ba} / \mathrm{Al}$ ratio is therefore 9500 6000 radiocarbon years (Figure 7).

The magnitudes of the $\mathrm{S} 1 \mathrm{Ba} / \mathrm{Al}$ values in the slowly accumulated S1 sediments are consistently higher than those in the rapidly accumulated S1 sediments (Figures 5 and 6 ). Given that $\mathrm{Ba} / \mathrm{Al}$ has been shown above to be related to initial $\mathrm{C}_{\text {org }}$ and that the slower accumulated cores are from deeper water depths, this observation is consistent with the report by Murat et al. [1990] that maximum $\mathrm{C}_{\text {org }}$ contents in $\mathrm{S} 1$ increase nearly linearly with water depth, from $1 \% \mathrm{C}_{\text {org }}$ at $1000 \mathrm{~m}$ to $3 \% \mathrm{C}_{\text {org }}$ at $3000 \mathrm{~m}$. A similar increase of maximum $\mathrm{Ba} / \mathrm{Al}$ ratio in $\mathrm{S1}$ units occurs with water depth (Figure 8). Recent sediment trap investigations have shown that $\mathrm{Ba}_{\text {bid }}$ / $\mathrm{C}_{\text {org }}$ ratios increase systematically with water depth, but the ratio is largely (75\%) set at depths $<1200 \mathrm{~m}$ with the additional $25 \%$ added between

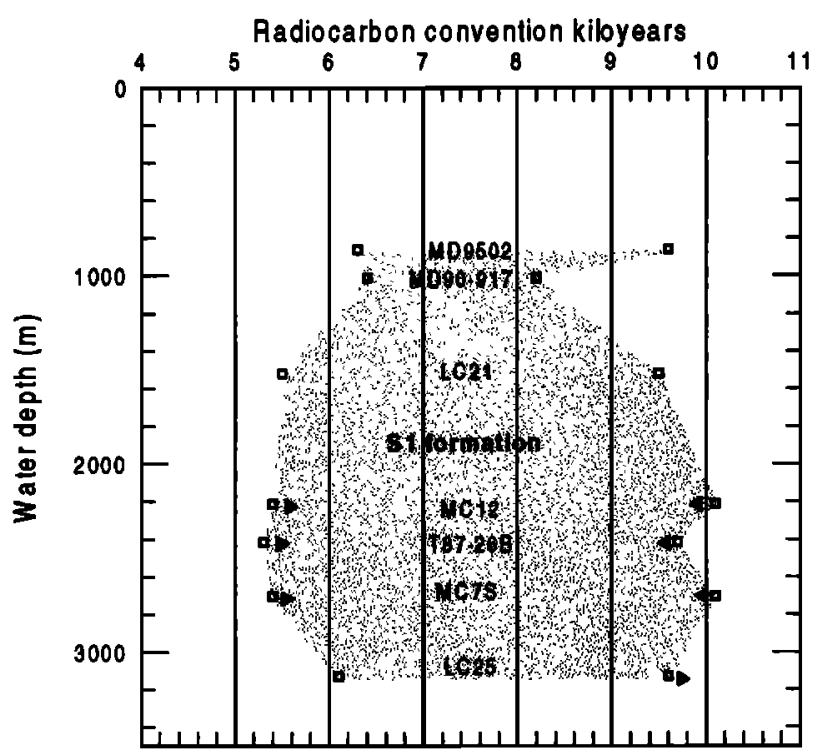

Figure 7. Start and finish times of the S1 sapropel, as indicated by the times of increase and decrease of the $\mathrm{Ba} / \mathrm{Al}$ weight ratio in the studied cores (Figure 6), as a function of water depth. The arrows show the expected direction in time of artifacts induced by bioturbation (T87-26B, MC7S, and MC12) or lost material (LC25).

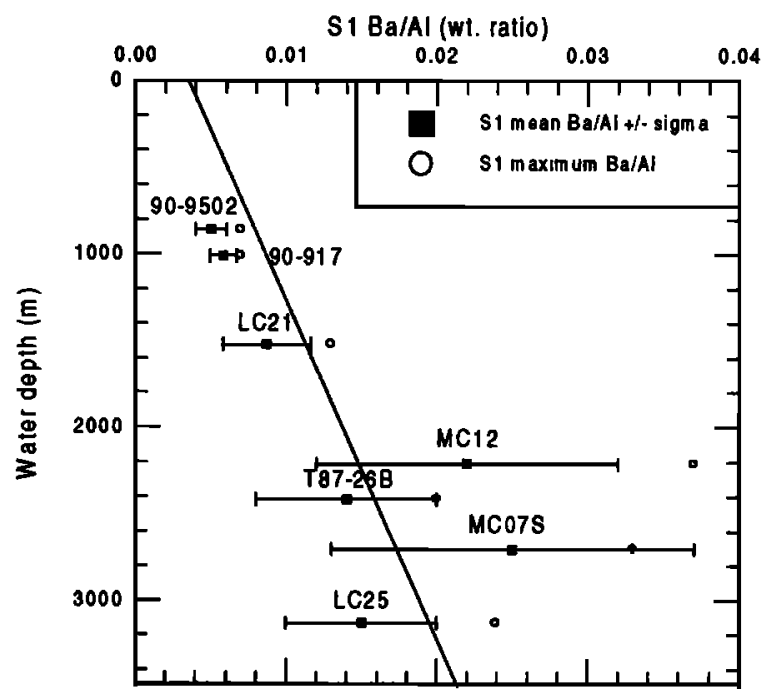

Figure 8. Mean $\mathrm{Ba} / \mathrm{Al}$ weight ratio $\pm 1 \sigma$ (squares) and maximum $\mathrm{Ba} / \mathrm{Al}$ weight ratio (circles) of the $S 1$ units in the studied cores as a function of water depth. The line is the regression of mean $\mathrm{Ba} / \mathrm{Al}$ on water depth. Figure 8 is similar to the presentation of Murat et al. [1990] of maximum $C_{\text {org }}$ contents in $S 1$ units versus water depth.

1200 and $3800 \mathrm{~m}$ [Dymond and Collier, 1996]. Recognizing this fact, the $\mathrm{Ba} / \mathrm{Al}$ data for all cores may be modeled to a first approximation as a constant $\mathrm{Ba}_{\mathrm{ba}}$ flux of $1000-1500 \mu \mathrm{g} \mathrm{cm}^{-2}$ $\mathrm{kyy}^{-1}$ superimposed on a variable background flux with a constant Al content of $49,000 \mathrm{ppm}$ (average $\mathrm{Al}$ content of all data in all cores), a $(\mathrm{Ba} / \mathrm{Al})_{\text {detnal }}$ ratio of 0.0035 (the background value suggested by Figure 5), and an assumed dry bulk density of $0.5 \mathrm{~g} \mathrm{~cm}^{-3}$ (Figure 9). It may be significant that the deepest and shallowest cores studied fall farthest above and below the model lines of Figure 9, respectively, compared with the remainder of the cores, which is what would be anticipated from the constant $\mathrm{Ba}_{\mathrm{bio}}$ flux approximation. Any effect of water depth on $\mathrm{Ba} / \mathrm{Al}$ or $\mathrm{C}_{\text {org }}$ content therefore appears secondary to flux dilution; that is, high $\mathrm{Ba} / \mathrm{Al}$ or $\mathrm{C}_{\text {org }}$ values in S1 are primarily a result of slower sediment accumulation rates with less dilution in deeper, more remote parts of the basin.

\subsection{Ventilation of the Eastern Mediterranean Sea During S1 Times?}

The differences in the timing of the S1 records above may result from different oxygenation histories of the water column in different parts of the basin. The salient features of the $\mathrm{Ba} / \mathrm{Al}$ profiles as a function of time are first that the saddle in the $\mathrm{Ba} / \mathrm{Al}$ ratio corresponding to the double sapropel phenomenon is observed only in the shallow depth cores LC21 (1522 m) and MD90-917 (1010 m) and to a lesser extent in MC12 (2211 m). The minimum $\mathrm{Ba} / \mathrm{Al}$ values are centered at 7500 years B.P. in all three cores. There is no such feature at this time in any other core, which are either from greater water depths (8726B, MC07S, and MC12) or from the southern half of the eastern Mediterranean basin (LC25) or from shallower water depth in the far east of the basin (MD9502). Second, the duration of the S1 unit in core MD90-917 is markedly shorter than in any of the other cores.

Double S1 sapropel units have been reported frequently from the southern Adriatic Sea [van Straaten, 1972; Fontugne et al., 1989] and from the northern Aegean Sea [Perissoratis 


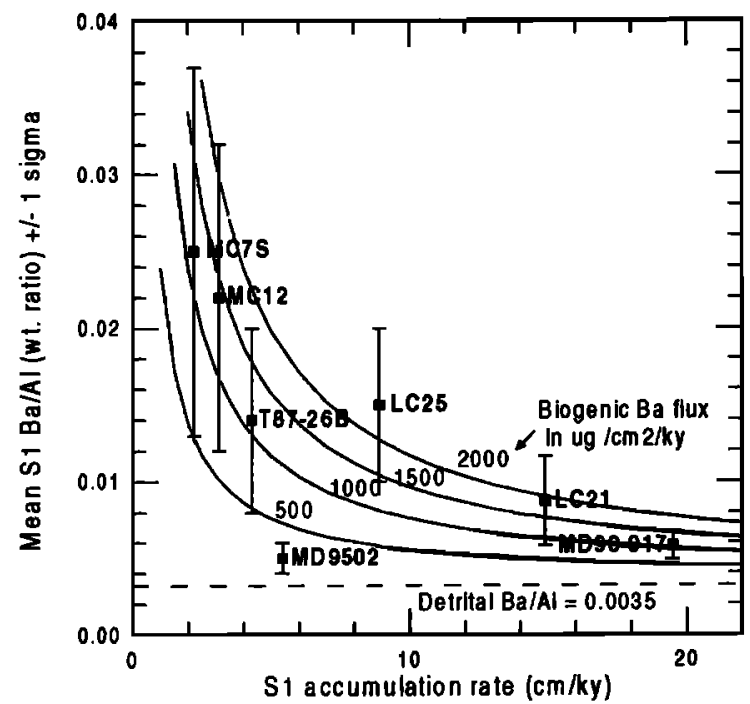

Figure 9. Mean $\mathrm{Ba} / \mathrm{Al}$ weight ratios $\pm 1 \sigma$ of the $\mathrm{S} 1$ units in the studied cores as a function of $S 1$ accumulation rate. The superimposed lines are modeled Ba/Al values produced by constant Babio fluxes of 500,1000 , 1500 , and $2000 \mathrm{~g} \mathrm{~cm}^{-2} \mathrm{kyr}^{-1}$ superimposed on a variable sediment accumulation with a constant $\mathrm{Al}$ contents of $49,000 \mathrm{ppm},(\mathrm{Ba} / \mathrm{Al})_{\text {detrite }}$ weight ratios of 0.0035 , and density of $0.5 \mathrm{~g} \mathrm{~cm}^{-3}$.

and Piper, 1992]. Rohling et al. [1997, p. 97] interpreted these central sections in Adriatic and Aegean cores as a "200 year interruption of Holocene sapropel formation." Despite the visual evidence of two separated dark units, however, the geochemical evidence is that the central section with lower $\mathrm{Ba} / \mathrm{Al}$ values does not record a return to conditions as oligotrophic as those which preceded and followed sapropel deposition (Figure 3).

Estimates of total S1 duration from the Adriatic are shorter (e.g., 8300-6300 years [Jorissen et al., 1993; Rohling et al., 1997]) than those from the Aegean (e.g., 9200-6400 years; [Perissoratis and Piper, 1992]. The thermohaline circulation of the eastern Mediterranean is complex but is driven by the formation of new deep water by increases in salinity and/or by cooling. At present, the ventilation of eastern Mediterranean deep water ( $>1000 \mathrm{~m}$ ) is maintained by a seasonal (winter) downwelling of denser, oxygenated water in the north of the basin from sources in the Adriatic and Aegean Seas [Wust, 1961; Malanotte-Rizzoli and Hecht, 1988; Schlitzer et al., 1991; Bethoux, 1993; Roether et al., 1996]. Times of sapropel formation are correlated convincingly with maxima in Northern Hemisphere insolation which produces monsoon conditions and high runoff into the eastern Mediterranean Sea. The resultant wetter and warmer conditions are believed to cause enhanced water column stabilization and hence limited winter ventilation during times of sapropel formation [Rossignol-Strick et al., 1982; Mangini and Schlosser, 1986; Bethoux, 1993; Rohling, 1994]. From a reinterpretation of several marine and land pollen records, Rossignol-Strick [1995] has proposed a duration of 9000-6000 years for the most recent period of high summer moisture and mild winters around the eastern Mediterranean.

If the $\mathrm{S} 1$ sapropel has an unusually short duration in the Adriatic Sea area compared with the remainder of the basin, it appears likely that ventilation may not have been shut down completely during $\mathrm{S} 1$ sapropel formation but rather may have been intermittent or present at a reduced level which was insufficient to oxygenate the deep water column of the entire basin. This is opposite to the contention of Fontugne et al. [1989] who interpret a very late resumption of ventilation from what may be a later diagenetic feature. It is implicit in this explanation that oxic deep waters will cause more remineralization of the $\mathrm{C}_{\text {org }}$ flux through the water column and on the seafloor, contrary to the interpretation of S.E. Calvert and coworkers [Calvert, 1983; Calvert and Pedersen, 1992].

Thomson et al. [1995] have argued that a prominent Mn peak coincident with the top of many $\mathrm{S} 1 \mathrm{Ba} / \mathrm{Al}$ profiles is evidence of bottom water reoxygenation at the end of $S 1$ formation. In slowly accumulated $S 1$ examples a second underlying $\mathrm{Mn}$ peak occurs within the high $\mathrm{Ba} / \mathrm{Al}$ region which marks the extent of postdepositional oxidation of S1 [van Santvoort et al., 1996]. A different (small) secondary Mn peak is present at the base of the $\mathrm{Ba} / \mathrm{Al}$ and $\mathrm{C}_{\text {org }}$ saddle in the two cores with well-developed double sapropels (Figure 10), but there is no corresponding feature in any other core. In a similar manner to the argument that the larger upper Mn peaks mark a return to higher bottom water oxygen levels, these smaller Mn peaks in cores MD81-LC21 and MD90-917 are consistent with the argument that the saddle feature represents a short period of improved deep water oxygenation within S1 times. The $\mathrm{Mn}$ oxyhydroxide forming these small $\mathrm{Mn}$ peaks must now be metastable in anoxic conditions, so that the peaks probably had higher $\mathrm{Mn}$ contents on formation. This contention of a temporarily increased bottom water oxygen content during the $S 1$ episode is substantiated compellingly by benthic foraminiferal evidence. In another Adriatic core with a double S1 sapropel, Rohling et al. [1997] found that while the two lobes of $\mathrm{SI}$ with high $\mathrm{C}_{\text {org }}$ contents were barren or had very low benthic foraminiferal contents, the intervening saddle section contained a reestablishment of benthic foraminifera which necessitates some level of bottom water oxygen. By extension of this explanation, the double sapropel observed in both the Adriatic and Aegean Seas may represent an episode of improved ventilation in these basins during $S 1$ times. This period is centered at 7500 years marine radiocarbon years B.P., which corresponds to a calibrated time of $\sim 7900$ cal B.P. (Figure 6). A Holocene excursion in climate close to 8200 B.P. is seen in many paleoclimatic records from diverse marine and terrestrial localities [Alley et al., 1997]. The cause of this short interval remains unknown, but it shares cold, dry, and windy characteristics with the last glacial and Younger Dryas periods. It appears likely that this cooler and less humid interval enabled intensified ventilation during the $S 1$ period which otherwise exhibits a much reduced ventilation caused by monsoonal conditions. From pollen records, Rossignol-Strick [1995] has also interpreted a brief excursion to dry/cold conditions at $\mathbf{- 8 0 0 0}$ years during the generally moist/warm 9000-6000 year period. During this excursion the semidesert Artemisia species increases in abundance while the Pistacia species indicative of mild winters decreases.

\section{Conclusions}

A reevaluation of the duration of the most recent sapropel in the eastern basin of the Mediterranean Sea has been undertaken using the $\mathrm{Ba} / \mathrm{Al}$ productivity index and AMS radiocarbon dating to define the timings of $S 1$ formation. The most rapidly accumulated $S 1$ sediments $\left(>10 \mathrm{~cm} \mathrm{kyr}^{-1}\right)$ are 


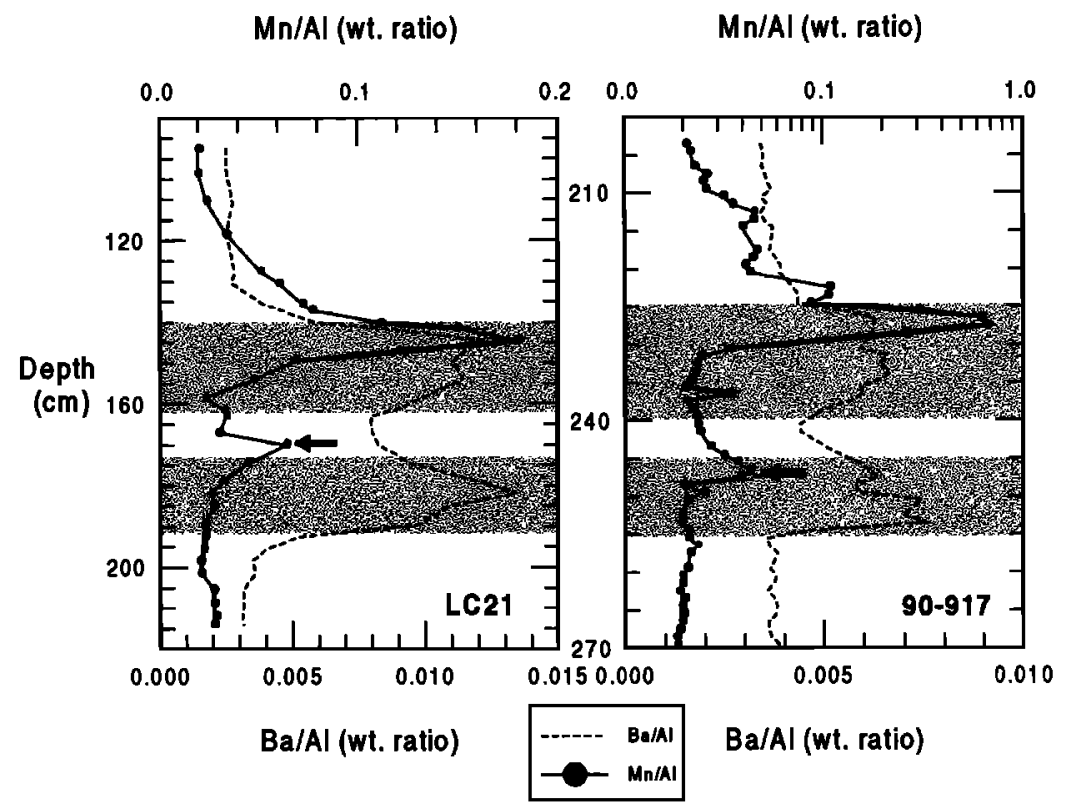

Figure 10. Mn/Al (solid line) and Ba/Al (dotted line) ratio profiles versus depth in cores LC21 and 90-917. Note the logarithmic scale for $\mathrm{Mn} / \mathrm{Al}$ in core 90-917. In each case a large Mn peak marks the end of high $\mathrm{Ba} / \mathrm{Al}$ values and the end of S1, but a small Mn peak (arrowed) also occurs toward the base of the $\mathrm{Ba} / \mathrm{Al}$ saddle section, consistent with some degree of oxygenation in the water column at that time. These smaller peaks are expected to be composed of $\mathrm{MnO}$, and therefore to be metastable in reducing conditions at the present time and to have been larger in the past.

unaffected by substantial post depositional oxidation because the $\mathrm{Ba} / \mathrm{Al}$ index correlates with $\mathrm{C}_{\text {org }}$ throughout the visual $\mathrm{S} 1$ units. Low accumulation rate $S 1$ sediments $\left(<5 \mathrm{~cm} \mathrm{kyr}^{-1}\right)$ consistently indicate a duration between $<10,000$ and 5300 marine radiocarbon convention years B.P., but more rapidly accumulated $S 1$ sediments generally indicate a somewhat shorter duration between -9500 and 6000 years B.P. This difference is interpreted as an artifact of bioturbation on either or both the $\mathrm{Ba} / \mathrm{Al}$ index and the dated foraminifera in slowly accumulated sediments rather than a water depth effect.

The S1 unit in the Adriatic Sea core studied has a shorter duration than in any other core, which is interpreted to mean that while ventilation may have been generally restricted during the S1 episode, it may not have been shut down fully or continuously. In this and two other cores from the north of the eastern Mediterranean basin, all from 1000-2200 m water depth, a simultaneous decrease in $\mathrm{C}_{\text {org }}$ and $\mathrm{Ba} / \mathrm{Al}$ levels during S1 occurs around 7500 radiocarbon years B.P. It is suggested that this "double sapropel" phenomenon is caused by a temporary resumption of ventilation in the source areas of new deep water (the Adriatic and Aegean Seas to the north of the basin) during the brief interval of global cooling at $8 \mathrm{kyr}$ in S1 time. This same cooling has already been reported in and around the eastern Mediterranean basin from pollen records, and an apparently simultaneous increase in deep water oxygenation has been reported in benthic foraminiferal records.

Acknowledgments. Samples for this work were obtained from the core repositories at Free University of Amsterdam, LSCE Gif-surYvette, and Southampton Oceanography Centre (BOSCOR). IFRTP is gratefully acknowledged for the recovery of many of the cores studied from their vessel Marion Dufresne. Twenty radiocarbon analyses were undertaken by the NERC Radiocarbon Laboratory through allocation 674/1296. This work was partly supported by the EU Marine Science and Technology SAP (MAS3-CT97-0137) and CLIVAMP (MAS3. CT95-0043) programs. We thank W. Dean, G.J. De Lange, and an anonymous reviewer for helpful reviews.

\section{References}

Alley, R.B., P.A. Mayewski, T. Sowers, M.Stuvier, K.C. Taylor, and P.U. Clark, Holocene climatic instability: A prominent, widespread event at 8200 yr ago, Geology, 25, 483-486, 1997.

Bard, E., Correction of accelerator mass spectrometry ${ }^{14} \mathrm{C}$ ages measured in planktonic foraminifera: Paleoceanographic implications, Paleoceanography, 3, 635-645, 1988.

Bethoux, J.-P., Mediterranean sapropel formation, dynamic and climatic viewpoints, Oceanol. Acta, 16, 127-133, 1993.

Boudreau, B.P., Is burial velocity a master parameter for bioturbation? Geochim Cosmochim. Acta, 58, 1243-1249, 1994.

Bruins, H.J., and J. van der Plicht, The Exodus enigma, Nature, 382, 213-214, 1996.
Calvert, S.E, Geochemistry of Pleistocene sapropels and associated sediments from the Eastern Mediterranean, Oceanol. Acta, 6, 255 267, 1983 .

Calvert, S.E, and T.F. Pedersen, Organic carbon accumulation and preservation in marine sediments: How important is anoxia? in Productivity, Accumulation and Preservation of Organic Matter in Recent and Ancien Sediments, edited by J.K. Whelan and J.W. Farrington, PP. 231-263, Columbia Univ. Press, New York, 1992.

Cita, M.B., C. Beghi, A. Camerlenghi, K.A Kastens, F.W. McCoy, A. Nosetto, E. Parisis, F. Scolari, and L. Tomadin, Turbidites and megaturbidites from the Herodotus Abyssal
Plian (Eastern Mediterranean) unrelated to seismic events, Mar. Geol. 55, 79-101, 1984.

De Lange, G.J., J.J. Middelburg, and P.A. Pruysers, Middle and Late Quatemary depositional sequences and cycles in the eastern Mediterranean, Sedimentology, 36, 151-158, 1989.

Dymond, J., and R. Collier, Particulate barium fluxes and their relationships to biological productivity, DeepSea Res., Part II, 43, 1283$1308,1996$.

Dymond, J., E. Suess, and M. Lyle, Barium in deep-sea sediment: A geochemical proxy for paleoproductivity, Paleoceanography, 7, 163181, 1992.

Emeis, K-C., et al., Paleoceanography and 
sapropel introduction, Proc. Ocean Drill. Program Init. Rep., 160, 21-28, 1996.

Fontugne, M.R., M. Pateme, S.E. Calvert, A. Murat, F. Guichard, and M. Amold, Adriatic deep water formation during the Holocene: Implication for the reoxygenation of the deep eastern Mediterranean, Poleoceanography. 4, 199-206, 1989

Fontugne, M., M. Amold, L. Labeyrie, M. Paterne. S.E. Calvert, and J-C. Duplessey, Paleoenvironment, sapropel chronology and Nile River discharge during the last 20,000 years as indicated by deep-sea sediment records in the eastern Mediterranean, in Late Quaternary Chronology and Paaleoclimates of the Eastern Mediterranean, edited by $O$. BarYosef and R.S. Kra, Radiocarbon, 34, 75-88, 1994.

Guichard, F., S. Carey, M.A. Arthur, H. Sigurdsson, and M. Amold, Tephra from the Minoan eruption of Santorini in sediments of the Black Sea, Nature, 363, 610-612, 1993.

Hardy, D.A., and A.C. Renfrew, (Eds) Thera and the Aegean World III, Thera Foun., London, 1990.

Hieke, W., Problems of Eastem Mediterranean Late Quatemary stratigraphy - a critical evaluation of literature, Meteor Forschungsergeb., Reihe C, 24, 68-88.

Higgs, N.C., J. Thomson, T.R.S. Wilson, and IW. Croudace, Modification and complete removal of eastern Mediterranean sapropels by postdepositional oxidation, Geology, 22, 423$426,1994$.

Jorissen, F.J., A. Asioli, A.M. Borsett, L. Capotiondi, J.P. de Visser, F.J. Hilgen, E.J. Rohling, K. van der Borg, C. Vergnaud Grazzini, and W.J. Zachariasse, Late Quaternary central Mediterranean biochronology, Mar. Micropaleontol., 21, 169189,1993 .

Kidd, R.B., M.B. Cita, and W.B.F. Ryan, Stratigraphy of eastem Mediterranean sapropel sequences recovered during DSDP Leg42A and their paleoenvironmental significance, Init. Rep. Deep Sea Drill. Proj., 42A, 421 443, 1978.

Kromer, B., and B. Becker, German oak and pine calibration, 7200-9439 BC, Radiocarbon, 35, $125-135,1993$

Kuniholm, P.I, B. Kromer, S.W. Manning, M. Newton, C.E. Latini, and M.J. Bruce, Anatolian tree rings and the absolute chronology of the eastern Mediterranean, 2200-718 BC, Nature, 381, 780-783, 1996.

Legeleux, F, J-L. Reyss, and S. Schmidt, Particle mixing rates in sediments of the northeast tropical Atlantic: Evidence from ${ }^{210} \mathrm{~Pb}$, ${ }^{137} \mathrm{Cs}$ ${ }^{220} \mathrm{Th}$ and ${ }^{234} \mathrm{Th}_{\mathrm{rs}}$ downcore distributions, Earth Planet. Sci. Left., 128, 545-562, 1994.

Lourens, L.J., A. Antonarakou, F.J. Hilgen, A.A.M. van Hoof, C. Vergnaud-Grazzini, and W.J. Zachariasse, Evaluation of the Plio-Pleistocene astronomical timescale, Paleoceanography, 11, $391-413,1996$.

Malanotte-Rizzoli, P., and A. Hecht, Large-scale properties of the eastem Mediterranean: A review, Oceanol. Acta, 11, 323-335, 1988.

Mangini, A., and P. Schlosser, The formation of eastem Mediterranean sapropels, Mar. Geol, $72,115-124,1986$.

Murat, A.R., G. Got, G. Cauwet, and R. Buscail,
Facteurs de la variabilite du taux de carbone organique du sapropele holocene de la Mediterranee orientale, Rapp. P.V. Reun. Cons. Int. Explor. Sci. Mer Mediter., 32, 45, 1990.

Passier, H.F., J.J. Middelburg, B.J.H. van Os, and G.J. de Lange, Diagenetic pyritisation under eastern Mediterranean sapropels caused by downward sulfide diffusion, Geochim Cosmochim. Acta, 60, 751-763, 1996

Perissoratis, C., and D.J.W. Piper, Age, regional variation, and shallowest occurrence of $S 1$ sapropel in the Northem Aegean Sea, Geo Mar. Lett. 12, 49-53, 1992.

Reeder, M., R.G. Rothwell, D.A.V. Stow, G. Kahler, and N.H. Kenyon, Turbidite flux architecture and chemostratigraphy of the Herodotus Basin, Levantine Sea, SE Mediterranean, in Geological Processes on Continental Margins: Sedimentation, MassWasting and Stability, edited by M.S. Stoker, D. Evans, and A. Cramp, Geol. Soc. Spec. Publ. 129, 19-41, 1998.

Roether, W., B.B. Manca, B. Klein, D. Bregant, D. Georgeopoulos, V. Beitzel, V. Kovacevic, and A. Luchetta, Recent changes in Eastern Mediterranean deep waters, Science, 27I, 333335, 1996.

Rohling, EJ., Review and new aspects concerning the formation of eastem Mediterranean sapropels, Mar. Geol., 122, 1-28, 1994.

Rohling, EJ., F.J. Jorissen, and H.C. de Stigter 200 year interruption of Holocene sapropel formation in the Adriatic Sea, J Micropaleontol., 16, 97-108, 1997.

Rossignol-Strick, M., Sea-land correlation of pollen records in the Eastern Mediterranean for the glacial-interglacial transition: Biostratigraphy versus radiometric time-scale, Quat. Sci. Rev. 14, 893-915, 1995.

Rossignol-Strick, M., W. Nesteroff, P. Olive, and C. Vergnaud-Grazzini, After the deluge: Mediterranean stagnation and sapropel formation, Nature, 295, 105-110, 1982.

Schlitzer, R., W. Roether, H. Oster, H-G. Junghans, M. Hausmann, H. Johannsen, and A. Michelato, Chlorofluoromethane and oxygen in the eastem Mediterranean, DeepSea Res., Part A, 38, 15311551, 1991.

Siani, G., Estimation de l'age $14 \mathrm{C}$ du reservoir des eaux de surface de la Mer Mediterranee pendan les demiers 18000ans. Relations avec la circulation oceanique, These Dr es Sciences, 164 pp., Universite Paris XI Orsay, 1999.

Siani, G., M. Paterne, M. Amold, E. Bard, B Metivier, N. Tisnerat, and F. Bassinot, Radiocarbon reservoir ages in the Mediterranean Sea and Black Sea Radiocarbon, in press, 1999.

Stanley, D.J., Mud redeposition and problems of assessing microfossil, isotopic and radiocarbon data in the Mediterranean, Mar. Geol., 62, 381$389,1985$.

Stroble, $K$, and M.D. Krom, Evidence for the evolution of an oxygen minimum layer at the beginning of S-1 sapropel deposition in the eastem Mediterranean, Mar. Geol., 140, 231$236,1997$.

Stuiver, M., and B. Becker, High-precision decadal calibration of the radiocarbon time scale, $A D$ 1950-6000 BC, Radiocarbon, 35, 35-65, 1993.

Stuiver, M., and T.F. Braziunas. Modeling atmospheric ${ }^{14} \mathrm{C}$ influences and ${ }^{14} \mathrm{C}$ ages of marine samples to $10,000 \mathrm{BC}$, Radiocarbon, 35 , 137-189, 1993

Thomson, J., N.C. Higgs, T.R.S. Wilson, IW Croudace, G.J. De Lange, and P.J.M. van Santvoort, Redistribution and geochemical behaviour of redox-sensitive elements around S1, the most recent eastem Mediterranean sapropel, Geochim. Cosmochim. Acta, 59 3487-3501, 1995

Thomson, J., D. Mercone, G.J. de Lange, and P.J.M. van Santvoort Review of recent advances in the interpretation of Eastern Mediterranean sapropel S1 from geochemical evidence, Mar. Geol., J53, 77-89, 1999.

Thunell, R.C., and D.F. Williams, GlacialHolocene salinity changes in the Mediterranean sea: Hydrographic and depositional effects, Nature, 338, 493-496, 1989.

Trauth, M.H., M. Samthein, and M. Amold, Bioturbational mixing depth and carbon flux at the sea floor, Palaeoceanography, 12, 517-526, 1997.

Troelstra, S.R., G.M. Ganssen, K. van der Borg, and A.F.M. de Jong, A Late Quatemary stratigraphic framework for Eastern Mediterranean sapropel S1 based on AMS 14C dates and stable oxygen isotopes, Radiocarbon, 33, 15-21, 1991.

van Santvoort, P.J.M., G.J. De Lange, J. Thomson, H. Cussen, T.R.S. Wilson, M.D. Krom and $K$. Strohle, Active post-depositional oxidation of the most recent sapropel (S1) in sediments of the eastern Mediterranean Sea, Geochim. Cosmochim. Acta, 60, 4007-4024, 1996.

van Santvoort, P.J.M., G.J. De Lange, C.G. Langereis, M.J. Dekkers, and M. Paterne, Geochemical and palaeomagnetic evidence for the occurrence of "mussing" sapropels in eastern Mediterranean sediments, Paleoceanography. 12, 773-786, 1997.

van Straaten, L.M.J.U., Holocene stages of oxygen depletion in deep waters of the Adsriatic Sea, in The Mediterranean Sea, edited by D.J. Stanley, PP 631-643, Van Nostrand Reinhold, New York, 1972.

Vergnaud-Grazzini, C., M. Devaux, and J. Znaidi, Stable isotope "anomalies" in Mediterranean Pleistocene records, Mar. Micropaleontol., IO. 35-69, 1986.

Wust, G., On the vertical circulation of the Mediterranean Sea, J. Geophys. Res., 66, 32613271,1961 .

IW. Croulace, D. Mercone, and J. Thomson, Southampton Oceanography Centre, Empress Dock, Southampton, SOl4 3ZH, England, UK. (docm @ soc.soton.ac.uk; john.thomson@ soc.soton. ac.uk)

M. Pateme and G. Siani, Laboratoire des Sciences du Climat et de l' Environment Laboratoire Mixte CNRS-CEA, Domaine du CNRS, F-91 198, Gif-sur-Yvette Cedex, France.

S. Troelstra, Institute of Earth Sciences, Free University, P.O. Box 7161, 1007, Amsterdam, Netherlands.

(Received April 15, 1999; revised November 15, 1999 . accepted November 22, 1999.) 